MirosŁaw WóJTowicz

Uniwersytet Pedagogiczny, Kraków

\title{
Wpływ światowego kryzysu gospodarczego na brazylijski i meksykański przemysł samochodowy
}

Przemysł samochodowy w Ameryce Łacińskiej skoncentrowany jest w dwóch, największych pod względem ludności oraz potencjału gospodarczego, państwach tego regionu: Brazylii i Meksyku. Sektor ten ma w obu krajach długie tradycje rozwoju, związane z realizowaną przez nie polityką industrializacji poprzez substytucję importu. Strategia ta skłaniała międzynarodowe koncerny do rozwijania w nich produkcji, co gwarantowało im dostęp do ich relatywnie dużego rynku wewnętrznego, chronionego przed importem z zagranicy wysokimi barierami celnymi (Berry i in. 1992; Wójtowicz 2008).

Odejście na początku lat 90. XX w. od polityki substytucji importu na rzecz liberalizacji polityki handlowej, prywatyzacji i otwarcia na napływ zagranicznych inwestycji, zmieniło uwarunkowania funkcjonowania koncernów samochodowych w obu państwach. Dodatkowym czynnikiem modyfikującym była integracja Meksyku w ramach NAFTA, a w przypadku Brazylii zacieśnianie współpracy handlowej w ramach MERCOSUR. Zaowocowało to dynamicznym wzrostem wielkości produkcji w tych państwach oraz napływem nowej fali inwestycji zagranicznych, związanych zarówno z produkcją samochodów, jak i części samochodowych (Berry i in. 1992; Carrillo 2000; Wójtowicz 2009).

Przemysł samochodowy w obu państwach cechował się innymi ścieżkami rozwoju i specjalizacji produkcyjnej, co będzie przedmiotem szczegółowej analizy w dalszej części pracy. Wpłynęło to również na odmienną reakcję sektora motoryzacyjnego na światowy kryzys gospodarczy, który szczególnie ostro dotknął duże koncerny międzynarodowe. Celem artykułu jest przedstawienie czynników i uwarunkowań krajowych oraz międzynarodowych wywierających decydujący wpływ na zmiany wielkości produkcji przemysłu samochodowego w Brazylii i Meksyku w latach 2000-2010, ze szczególnym uwzględnieniem światowego kryzysu gospodarczego lat 2008-2009. Dodatkowo zbadano wpływ światowego kryzysu gospodarczego na funkcjonowanie głównych koncernów samochodowych obecnych w Brazylii i Meksyku, a także przeanalizowano politykę gospodarczą tych państw pod kątem działań przeprowadzonych w celu zmniejszenia skutków kryzysu w przemyśle motoryzacyjnym.

\section{PrZEMYSŁ SAMOCHOdOWy MEKSYKu}

Przemysł samochodowy w Meksyku stanowi jeden z najważniejszych sektorów gospodarki. Składa się on z 20 fabryk produkujących samochody oraz ponad 2000 fabryk części samochodowych rozrzuconych w 26 stanach. Łącznie w tym sektorze zatrudnionych jest formalnie ponad $1 \mathrm{mln}$ pracowników, co stanowi 13,5\% całego zatrudnienia w przemyśle. 
Według danych za 2008 r., sektor ten dostarczył 16\% PKB wytworzonego przez przemysł przetwórczy i 3,8\% całkowitego PKB Meksyku oraz 20\% wartości eksportu sektora przemysłowego (Carrillo i in. 2009).

Meksykański sektor motoryzacyjny przeżywał szczególnie dynamiczny rozwój od rozpoczęcia funkcjonowania NAFTA w styczniu 1994 r., o czym świadczy dynamiczny wzrost produkcji samochodów z 1,09 mln sztuk w tym roku do 2,18 mln sztuk w 2008 r., czyli o $100 \%$. W ciągu tego okresu meksykańscy badacze wyróżniają trzy główne fazy jego rozwoju. Pierwsza z nich obejmuje lata 1995-2000 i cechuje się dynamicznym wzrostem eksportu. Było to wynikiem wykorzystywania przez firmy działające w Meksyku możliwości powstałych po utworzeniu NAFTA. Kolejna faza, obejmująca lata 2001-2005, cechowała się stagnacją wielkości produkcji, szczególnie tej skierowanej na eksport, co wynikało z wahań kursów wymiany, wzrostu inflacji i spowolnienia gospodarczego w USA. Ostatnia faza rozpoczęła się w 2005 i skończyła w 2008 r. Cechowało ją dynamiczne zwiększenie produkcji, poprawa wydajności pracy, wprowadzenie nowych modeli i ekspansja eksportowa na nowe rynki (Alvarez i in. 2010).

W ostatniej fazie przed wybuchem kryzysu ogólna wielkość produkcji samochodów w Meksyku wzrosła o 29,1\%, z 1,69 do 2,18 mln sztuk. Szczególną rolę odegrała w niej produkcja eksportowa, która wzrosła o 39,6\%, co sprawiło, że jej udział podniósł się z 70,7\% do 76,4\% ogólnej wielkości produkcji. Z końcem 2008 r. zaczęły się jednak uwidaczniać pierwsze symptomy kryzysu w postaci spadku sprzedaży (szczególnie na rynku USA), co skutkowało zmniejszeniem eksportu i zmusiło koncerny do ograniczenia produkcji. W 2009 r. wielkość produkcji samochodów w Meksyku spadła o 28,1\% w porównaniu z 2008 r., przy czym produkcja na eksport zmniejszyła się o $26,3 \%$, natomiast produkcja na rynek krajowy zmalała aż o 33,9\%. Biorąc pod uwagę fakt, iż - wg danych OICA - światowa produkcja przemysłu motoryzacyjnego w tym okresie spadła o 12,8\%, można stwierdzić, że meksykański przemysł samochodowy zanotował wyjątkowo silne załamanie produkcji (ryc. 1).

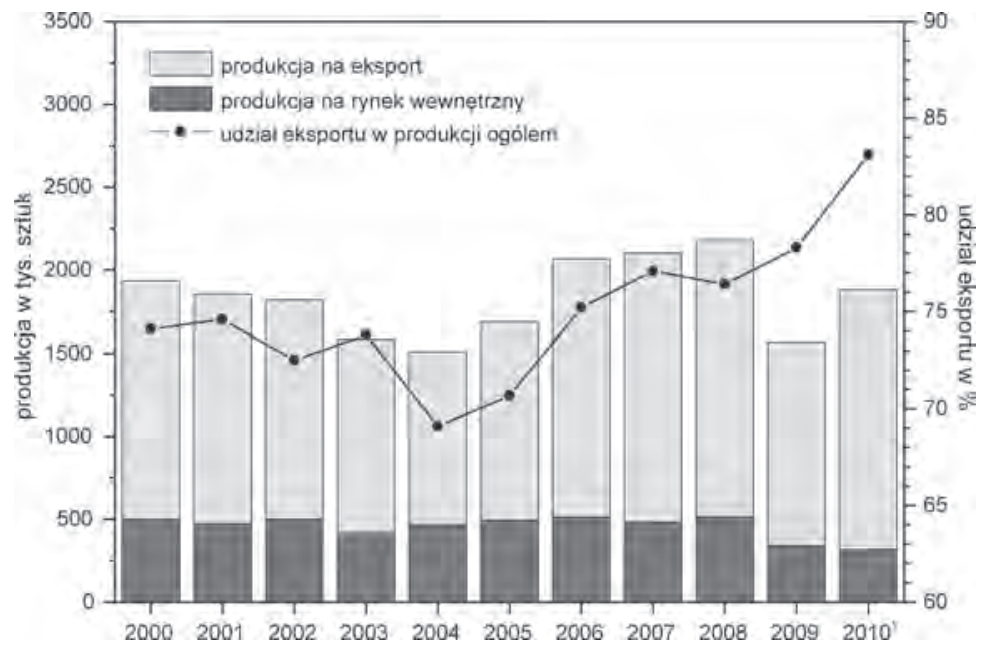

Ryc. 1. Zmiany wielkości produkcji samochodów oraz udziału eksportu w ogólnej produkcji w Meksyku w latach 2000-2010

1 - wielkość produkcji za 10 miesięcy $2010 \mathrm{r}$.

Źródło: opracowanie na podstawie danych z AMIA 2010 
Okresem szczególnie ostrego załamania był przełom 2008 i 2009 r. Pomiędzy październikiem a styczniem wielkość produkcji spadła o 62,0\%, z 214,6 do 81,5 tys. sztuk. Niski poziom produkcji utrzymywał się w całym pierwszym półroczu 2009 r., kiedy wyprodukowano jedynie 602,5 tys. sztuk, czyli o 42,9\% mniej w porównaniu z pierwszym półroczem 2008 r., w którym produkcja wyniosła aż 1054,8 tys. sztuk (ryc. 2). Kryzys przemysłu motoryzacyjnego objął wszystkie państwa NAFTA, o czym świadczy fakt, iż w dwóch pierwszych miesiącach 2009 r. wielość produkcji zmalała o $57,5 \% \mathrm{w}$ porównaniu z tym samym okresem poprzedniego roku. Największy spadek zanotowano w USA (o 61,5\%) oraz Kanadzie (o 55,6\%), podczas gdy w przypadku Meksyku był on relatywnie najmniejszy i wynosił 46,4\% (Alvarez i in. 2009).

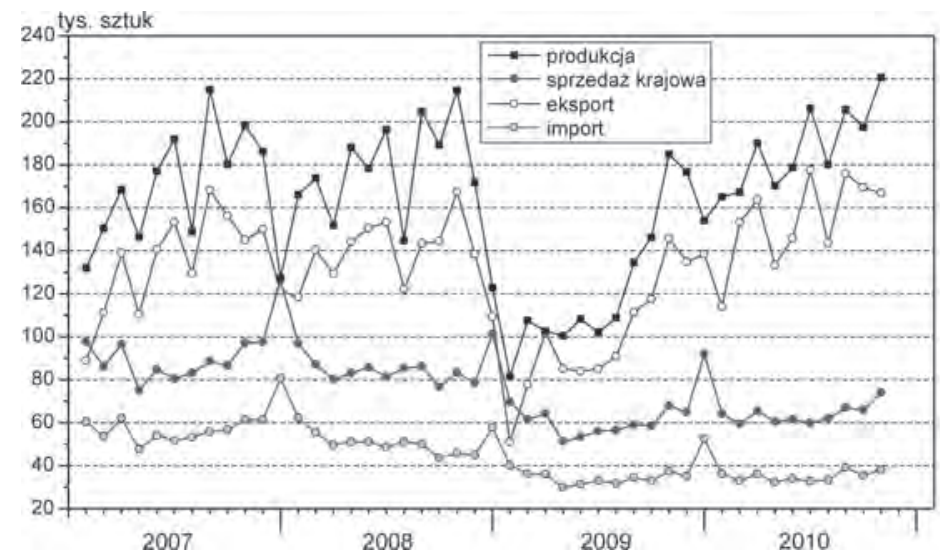

Ryc. 2. Zmiany wielkości produkcji, sprzedaży krajowej, eksportu i importu samochodów w Meksyku w latach 2007-2010 wg miesięcy

Źródło: opracowanie na podstawie danych z AMIA 2010

Spadek produkcji meksykańskiego przemysłu samochodowego był głównie wynikiem załamania eksportu samochodów do najważniejszego odbiorcy, czyli USA. W pierwszym półroczu 2009 r. wielkość eksportu samochodów z Meksyku wynosiła jedynie 484,7 tys. sztuk i była o 42,0\% mniejsza w porównaniu z tym samym okresem roku poprzedniego. Jednakże już w drugiej połowie roku zaobserwowano wyraźne ożywienie produkcji eksportowej, związane z ożywieniem sprzedaży na rynku USA oraz w Europie Zachodniej. Wyeksportowano wówczas ponad 825,2 tys. sztuk pojazdów, czyli aż o 70,2\% więcej w porównaniu z pierwszym półroczem. Eksport wykazuje także ogólną tendencję wzrostową w świetle danych z pierwszych 10 miesięcy 2010 r., co pozwala mieć nadzieję na szybkie wyjście z kryzysu i poprawę sytuacji finansowej meksykańskiego sektora motoryzacyjnego (ryc. 2).

W przeciwieństwie do ożywienia eksportu, w sprzedaży na rynek krajowy nie odnotowano poprawy sytuacji. Po spadku średniomiesięcznej sprzedaży samochodów z poziomu ok. 85 tys. w 2008 r. do ok. 63 tys. w 2009 r., również w ciagu 10 miesięcy 2010 r. pozostała ona na podobnym poziomie, ok. 64 tys. sztuk. Wynika to głównie ze specjalizacji funkcjonujących w Meksyku koncernów w produkcji droższych i większych modeli samochodów dostosowanych do potrzeb konsumentów z USA. Brak w ofercie miejscowych firm małych i tanich aut kompaktowych sprawia, iż ich niedobór na rynku uzupełniany jest importem. W 2008 r. wyniósł on 611,3 tys. sztuk, zaś w 2009 r. był o 29,5\% mniejszy, sięgając 
blisko 430,7 tys. sztuk. W tym samym czasie sprzedaż krajowych modeli spadła o 26,4\% z 1 025,5 do 754,9 tys. sztuk, co sprawia, iż udział importu w ogólnej sprzedaży samochodów jedynie nieznacznie się zmniejszył z 37,3\% do 36,3\% (ryc. 2).

Stagnacja wielkości sprzedaży nowych samochodów w Meksyku jest też w dużej mierze wynikiem importu (często nielegalnego) używanych aut, głównie ze Stanów Zjednoczony i Kanady. Stanowią one dużą konkurencję dla nowych samochodów, zwłaszcza w sytuacji gdy obywateli USA zachęca się dopłatami do wymiany starych aut, które następnie w większości trafiają na rynek meksykański (Alvarez i in. 2009).

\section{WPŁYW KRYZYSU NA FUNKCJONOWANIE KONCERNÓW SAMOCHODOWYCH W MEKSYKU}

Załamanie produkcji samochodów wywołane światowym kryzysem gospodarczym dotknęło wszystkie koncerny samochodowe działające na rynku meksykańskim, skutkując znacznymi ograniczeniami produkcji, co wynikało ze spadku zapotrzebowania na nowe samochody. W przypadku Meksyku bardzo duże znaczenie miało silne powiązanie produkcji z rynkiem zbytu do sąsiednich Stanów Zjednoczonych, gdzie załamał się popyt na nowe auta, co wpędziło w kłopoty główne amerykańskie koncerny samochodowe: General Motors, Chrysler i Ford Motor. Firmy te traktowały swoje meksykańskie zakłady jako zaplecze produkcyjne, które dostarcza wyroby na amerykański rynek, wykorzystując tańsze koszty pracy w Meksyku oraz porozumienia o wolnym handlu w ramach NAFTA. W szczycie kryzysu gospodarczego, przypadającym na pierwsze dwa miesiące 2009 r., to one odnotowały największy spadek produkcji w Meksyku, sięgający odpowiednio: 85,5\% w przypadku Forda, 50,5\% w przypadku Chryslera i 45,5\% w przypadku General Motors, w porównaniu z tym samym okresem wcześniejszego roku (tab. 1).

Tab. 1. Spadek wielkości produkcji głównych koncernów samochodowych w Meksyku w styczniu i lutym 2008 i 2009 r.

\begin{tabular}{|l|r|r|r|}
\hline Firmy & 2008 & 2009 & Spadek w \% \\
\hline Chrysler & 40653 & 20108 & $-50,5$ \\
\hline Ford Motor & 51616 & 7407 & $-85,5$ \\
\hline General Motors & 82789 & 45101 & $-45,5$ \\
\hline Honda & 8484 & 7956 & $-6,2$ \\
\hline Nissan & 71144 & 50156 & $-29,5$ \\
\hline Toyota & 8192 & 6809 & $-16,9$ \\
\hline Volkswagen & 77158 & 51543 & $-33,2$ \\
\hline Ogółem & $\mathbf{3 4 0 ~ 0 3 6}$ & $\mathbf{1 8 9 0 8 0}$ & $-\mathbf{4 4 , 4}$ \\
\hline
\end{tabular}

Źródło: opracowanie własne na podstawie danych AMIA 2010 
W przypadku pozostałych koncernów skala spadku produkcji okazała się znacznie mniejsza, co w dużej mierze wiązało się z ich większym nastawieniem na rynek wewnętrzny, ale także wynikało ze struktury produkcji, w której większą rolę odgrywają mniejsze i tańsze samochody kompaktowe, a zapotrzebowanie na ten typ pojazdów zmniejszyło się relatywnie najmniej. Załamanie produkcji meksykańskich oddziałów koncernów tzw. wielkiej trójki z Detroit wynikało także w dużej mierze z ich problemów w kraju macierzystym, co skutkowało ograniczeniem produkcji, czasowymi zatrzymywaniem pracy zakładów i wysyłaniem pracowników na przymusowe zwolnienia (Foreign Direct Investment 2010, s. 96).

Szczególnie kryzysowe w przypadku Meksyku okazało się pierwsze półrocze 2009 r., w którym nastapiło wyraźne spowolnienie produkcji, dotykające głównie amerykańskie koncerny. Sytuacja poprawiła się dopiero w drugiej połowie 2009 r., w dużej mierze z powodu ustabilizowania się sytuacji koncernów w ich macierzystym kraju dzięki pomocy rządu Stanów Zjednoczonych ${ }^{1}$. Ważną rolę odegrało także pobudzenie przez rząd USA popytu na nowe samochody, dzięki ogłoszeniu programu dopłat do wymiany starych aut (Car Allowance Rebate System), zwany popularnie „pieniądze za gruchoty” (Cash for Clunkers). Na dopłaty w ramach tego programu zaplanowano 3 mld dolarów, które dzięki bardzo dużej popularności zostały bardzo szybko wydane w lipcu i sierpniu 2009 r. ${ }^{2}$ Najważniejszymi beneficjentami programu były koncerny amerykańskie, co przyczyniło się także do wzrostu produkcji samochodów w Meksyku, gdzie znajdują się ich główne zakłady produkcyjne (Foreign Direct Investment 2010).

Restrukturyzacja głównych amerykańskich koncernów przywróciła im nadszarpniętą wiarygodność wśród amerykańskich konsumentów, a program dopłat do wymiany samochodów zwiększył popyt, co w konsekwencji ponownie ożywiło produkcję pojazdów w Meksyku w drugiej połowie 2009 r. i sprawiło, iż ogólne załamanie produkcji w tym roku było mniejsze niż w pierwszych jego miesiącach. Przeprowadzone działania restrukturyzacyjne oraz poprawa funkcjonowania meksykańskich zakładów głównych koncernów samochodowych zaowocowały w kolejnym roku dynamicznym wzrostem produkcji, co było odpowiedzią na poprawę koniunktury na rynkach światowych i wzrost zapotrzebowania na nowe samochody. W przypadku Forda, który samodzielnie dokonał procesu restrukturyzacji i nie był zmuszony ogłaszać bankructwa, wielkość produkcji w pierwszych dziesięciu miesiącach 2010 r. była już o 2,8\% większa od ogólnej wielkości produkcji w 2008 r. W przypadku GM wielkość produkcji w pierwszych 10 miesiącach 2010 r. wyniosła 93,3\% produkcji z 2008 r., a w przypadku Chryslera 78,7\% (ryc. 3).

${ }^{1}$ Prezydent USA George Bush ogłosił w grudniu 2008 r. pakiet pomocowy w wysokości 17,4 mld USD dla koncernów GM i Chrysler. Program zaakceptował i wspierał także nowo wybrany prezydent Barack Obama. Firmy te otrzymały natychmiastową wsparcie w wysokości 9,4 mld USD dla GM oraz 4 mld USD dla Chryslera, a w przypadku GM także dostęp do dodatkowych 4 mld USD w lutym 2009 r. Nie uchroniło to jednak tych koncernów przed bankructwem. Chrysler ogłosił je w maju 2009 r. i było ono częścią umowy pomocowej zawartej z koncernem Fiat. Miesiąc później bankructwo ogłosił GM i oba koncerny rozpoczęły proces restrukturyzacji zadłużenia, ograniczenia działalności nieopłacalnych i przywrócenia rentowności. Po niecałych dwóch miesiącach koncerny przeszły proces restrukturyzacji i pojawiły się jako nowe, znacznie mniejsze i sprawniejsze podmioty. General Motors stał się w większości państwową firmą, gdyż w wyniku udzielonej pomocy 60,8\% akcji przypadło rządowi USA, a kolejne $11,7 \%$ rządowi Kanady i prowincji Ontario. Po restrukturyzacji Chryslera pojawił się nowy, mniejszy koncern z czystym bilansem - Chrysler Group LLC - wspierany przez Fiata (Foreign Direct Investment 2010, s. 77-78).

${ }^{2}$ Program ,ppieniądze za gruchoty” przewidywał rabaty w wysokości do 4,5 tys. USD dla osoby wymieniającej stary samochód na nowy, bardziej oszczędny model (Foreign Direct Investment 2010, s. 78). 


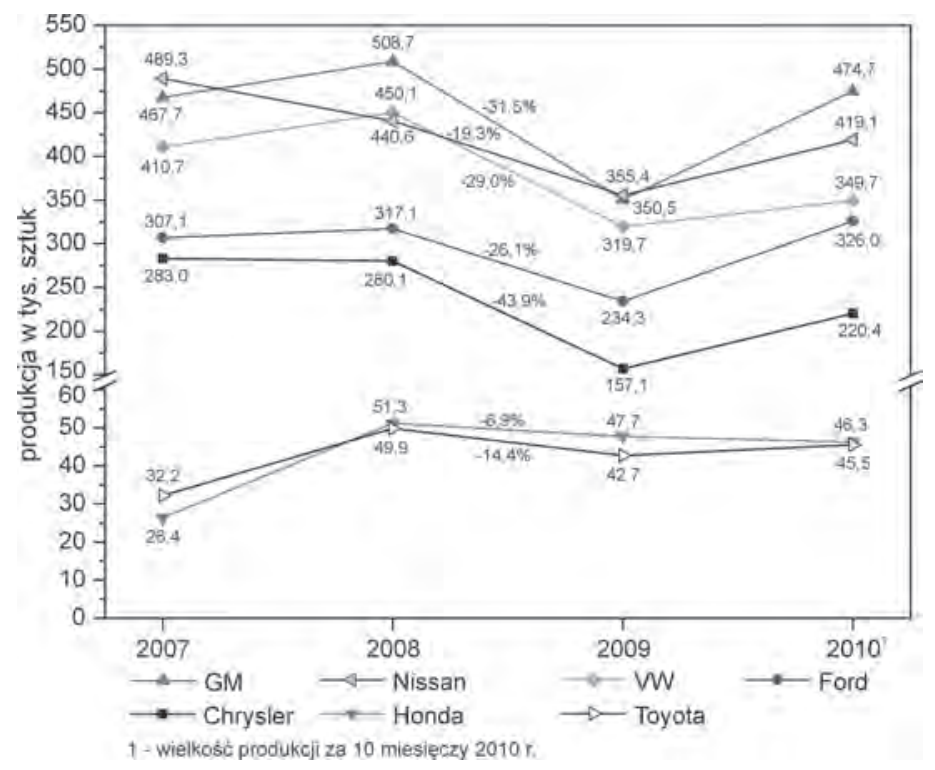

Ryc. 3. Zmiany wielkości produkcji głównych koncernów motoryzacyjnych w Meksyku w latach 2007-2010

Źródło: opracowanie na podstawie danych z AMIA 2010

\section{PrZEMYSL SAMOCHODOWy BraZYLII}

Brazylijski sektor motoryzacyjny jest największy w skali całej Ameryki Łacińskiej i w przeciwieństwie do Meksyku ma na celu przede wszystkim zaspokajanie rosnącego popytu krajowego. Mniej istotną rolę odgrywa w nim eksport, skierowany głównie do państw sąsiednich. Od początku lat 90 . XX w. sektor ten przechodzi gwałtowne przekształcenia związane $\mathrm{z}$ modernizacją istniejących zakładów, pojawieniem się licznych nowych koncernów, co doprowadziło do znacznego zwiększenia mocy produkcyjnych, urozmaicenia i unowocześnienia produkcji oraz oferowanych towarów. Okres ten można podzielić na trzy główne fazy. Pierwsza z nich, trwająca od początku lat 90. do $1998 \mathrm{r}$., związana była $\mathrm{z}$ ogólnymi przemianami paradygmatu rozwoju gospodarczego Brazylii, co wiązało się z odejściem od polityki industrializacji poprzez substytucję importu w kierunku polityki liberalizacji handlu, otwarcia się na inwestycje zagraniczne, prywatyzację oraz ograniczenie ingerencji rządu w gospodarkę. Odnotowano wówczas dynamiczny wzrost wielkości produkcji oraz napływ nowych inwestycji, szczególnie po 1995 r., gdy wprowadzono politykę zachęt inwestycyjnych. Kolejna faza, obejmująca lata 1998-2003, rozpoczęła się wraz z azjatyckim kryzysem gospodarczym i cechowała się spadkiem produkcji oraz sprzedaży na rynek wewnętrzny, co przy rozbudowanym wcześniej potencjale produkcyjnym skutkowało znacznym niewykorzystaniem mocy produkcyjnych i skłaniało koncerny do ukierunkowania na eksport. Zwiększenie dostaw na rynki zagraniczne było możliwe dzięki unowocześnieniu produkcji dokonanemu we wcześniejszej fazie, a także dewaluacji miejscowej waluty, co podnosiło konkurencyjność brazylijskich samocho- 
dów ${ }^{3}$. Trzecia faza obejmuje lata 2003-2009 i cechuje ją ponowny dynamiczny wzrost produkcji oraz sprzedaży na rynek krajowy (Wójtowicz 2008, 2009; Foreign Direct Investment 2010; Salerno, Arbix 2010).

W latach 2003-2008 wielkość produkcji wzrosła o 75,9\%, z 1,8 do 3,2 mln sztuk, natomiast wielkość rejestracji nowych samochodów zwiększyła się o 119,9\%, z 1,4 w 2003 r. do 3,1 mln sztuk w 2009 r. W wyniku tak dużego zapotrzebowania na nowe samochody stopniowo malała wielkość ich eksportu przy jednoczesnym wzroście importu. W związku z nastawieniem brazylijskiego przemysłu samochodowego na obsługe gwałtownie rosnącego popytu na rynku krajowym, skutki światowego kryzysu gospodarczego nie wpłynęły znacząco na ten sektor, a produkcja w latach 2008-2009 spadła zaledwie o 1,0\%. Szczególnie duży spadek odnotowano w przypadku produkcji eksportowej, która zmniejszyła się o 35,3\% w porównaniu do 2008 r., podczas gdy produkcja na rynek krajowy wzrosła w tym samym czasie o $9,1 \%$ (ryc. 4 ).

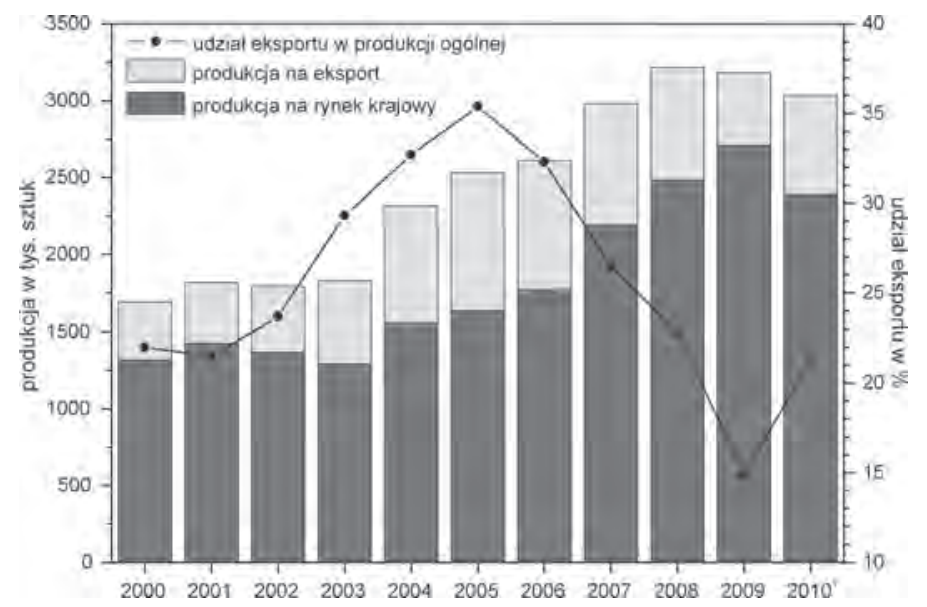

Ryc. 4. Zmiany wielkości produkcji samochodów oraz udziału eksportu w ogólnej produkcji w Brazylii w latach 2000-2010

1 - wielkość produkcji za 10 miesięcy $2010 \mathrm{r}$.

Źródło: opracowanie na podstawie danych z ANFAVEA 2010

Podobnie jak w Meksyku, największe załamanie produkcji nastąpiło w Brazylii na przełomie 2008 i 2009 r. Największy spadek produkcji (o 67,3\%) miał miejsce między październikiem a grudniem 2008 r., kiedy to spadła ona z 297,2 do 97,0 tys. sztuk. Jednakże w pierwszych miesiącach 2009 r. produkcja wykazywała dynamiczny wzrost, zbliżając się do poziomu sprzed kryzysu. W ujęciu półrocznym wielkość produkcji w pierwszej połowie 2009 r. była już tylko o 13,1\% mniejsza niż w pierwszym półroczu 2008 r., natomiast produkcja z drugiego półrocza była już o 12,4\% większa niż w drugim półroczu 2008 r.

Światowy kryzys gospodarczy, który dotknął brazylijski przemysł samochodowy na przełomie 2008 i 2009 r., udało się stosunkowo szybko opanować dzięki polityce prowadzonej przez rząd brazylijski, polegającej na wsparciu wzrostu krajowej konsumpcji poprzez

\footnotetext{
${ }^{3}$ W latach 1997-2003 produkcja przemysłu samochodowego notowała średnioroczny spadek o 1,8\%, a sprzedaż na rynku krajowym spadała średniorocznie o 4,6\%, podczas gdy eksport zwiększał się o 6,3\% (Foreign Direct Investment 2010, s. 86).
} 
uruchomienie przez Bank Brazylii środków finansowych dla banków komercyjnych, aby mogły one zintensyfikować akcję kredytową oraz obniżyć koszty kredytu przez zmniejszenie stóp procentowych ${ }^{4}$.

Drugim działaniem rządu było obniżenie podatku od wyrobów przemysłowych (Imposto sobre Produtos Industrializados - IPI). W przypadku samochodów o pojemności do $1000 \mathrm{~cm}^{3}$ został on zredukowany do zera, natomiast w przypadku pojazdów z silnikiem od 1000 do $2000 \mathrm{~cm}^{3}$ obniżony o połowę, a następnie jeszcze niżej do 5,5\% wartości samochodu, jeżeli zamontowany w nim silnik był ekologiczny (flex-fuel) i umożliwiał jednoczesne wykorzystanie benzyny i etanolu. Od października 2009 r. stawki podatku IPI zaczęto stopniowo podnosić do poziomu sprzed kryzysu, a w listopadzie 2009 r. ogłoszono utrzymanie jego niższej stawki w przypadku pojazdów z silnikiem flex-fuel, co miało być zachętą od zakupu bardziej ekonomicznych i przyjaznych dla środowiska samochodów (Foreign Direct Investment 2010, s. 94).

Działania zwiększające chłonność brazylijskiego rynku wewnętrznego okazały się skuteczne i po spadku sprzedaży na przełomie 2008 i 2009 r. odnotowano jej gwałtowny wzrost, wyprzedzający w pierwszych miesiącach 2009 r. wielkość średniej miesięcznej produkcji. W drugiej połowie roku wielkość sprzedaży spadła, jednak nadal utrzymywała się na poziomie niewiele odbiegającym od średniej miesięcznej wielkości produkcji. W skali całego 2009 r sprzedaż wyniosła ponad $3207 \mathrm{mln}$ sztuk samochodów i była o ok. 0,7\% wyższa od produkcji wynoszącej 3,183 mln sztuk (ryc. 5).

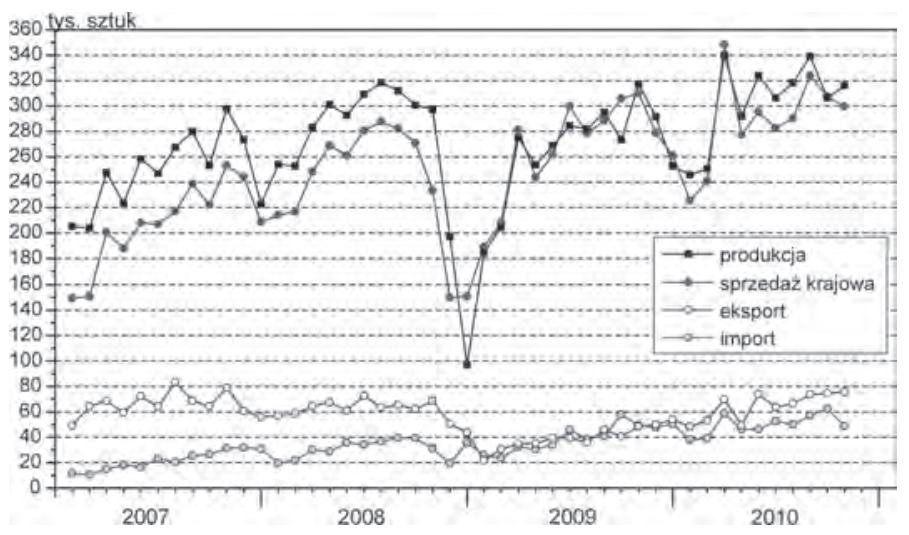

Ryc. 5. Zmiany wielkości produkcji, sprzedaży krajowej, eksportu i importu samochodów w Brazylii w latach 2007-2010 wg miesięcy

Źródło: opracowanie na podstawie danych z ANFAVEA 2010

Tak gwałtowny wzrost sprzedaży, przekraczający w skali całego 2009 r. wielkość produkcji, wpłynął na ożywienie importu, który wykazywał stopniowy wzrost w kolejnych miesiącach, z poziomu ok. 20 tys. do ok. 50 tys. sztuk miesięcznie. W skali całego roku osiagnął on wielkość ponad 476 tys. sztuk, czyli o 28,3\% więcej niż w 2008 r., kiedy to wyniósł ok. 371 tys. sztuk (ryc. 5).

${ }^{4}$ Stopa procentowa spadła w Brazylii z 37,7\% w listopadzie 2008 r. do 24,9\% we wrześniu 2009 r., co zwiększyło udzielone kredyty samochodowe z 82 mld USD w grudniu 2008 r. do 90 mld USD w sierpniu 2009 r. Stanowiły one 34\% ogółu pożyczek zaciagniętych przez osoby fizyczne (Foreign Direct Investment 2010, s. 94). 


\section{WPŁYW KRYZYSU NA FUNKCJONOWANIE KONCERNÓW SAMOCHODOWYCH W BRAZYLII}

Korzystną sytuację na brazylijskim rynku motoryzacyjnym starały się wykorzystać wszystkie główne koncerny obecne w tym kraju. Szczególnie dynamiczny wzrost produkcji odnotował Ford (o 6,6\% w porównaniu z 2008 r.), a następnie Fiat (o 2,0\%) i Volkswagen (o 1,0\%). Warto podkreślić, iż w ostatnich latach Volkswagen wyprzedził Fiata i stał się największym producentem na brazylijskim rynku, z planami osiagnięcia w 2012 r. poziomu produkcji $1 \mathrm{mln}$ sztuk aut rocznie. Spośród czterech najważniejszych graczy najgorsze wyniki notował koncern General Motors, szczególnie w pierwszej połowie 2009 r. Było to w dużej mierze następstwem problemów finansowych, jakie koncern miał w kraju macierzystym. Niemniej jednak udało mu się zachować pozycję na brazylijskim rynku, a wielkość produkcji w 2009 r. spadła tylko o 0,8\% w porównaniu z rokiem poprzednim (ryc. 6).

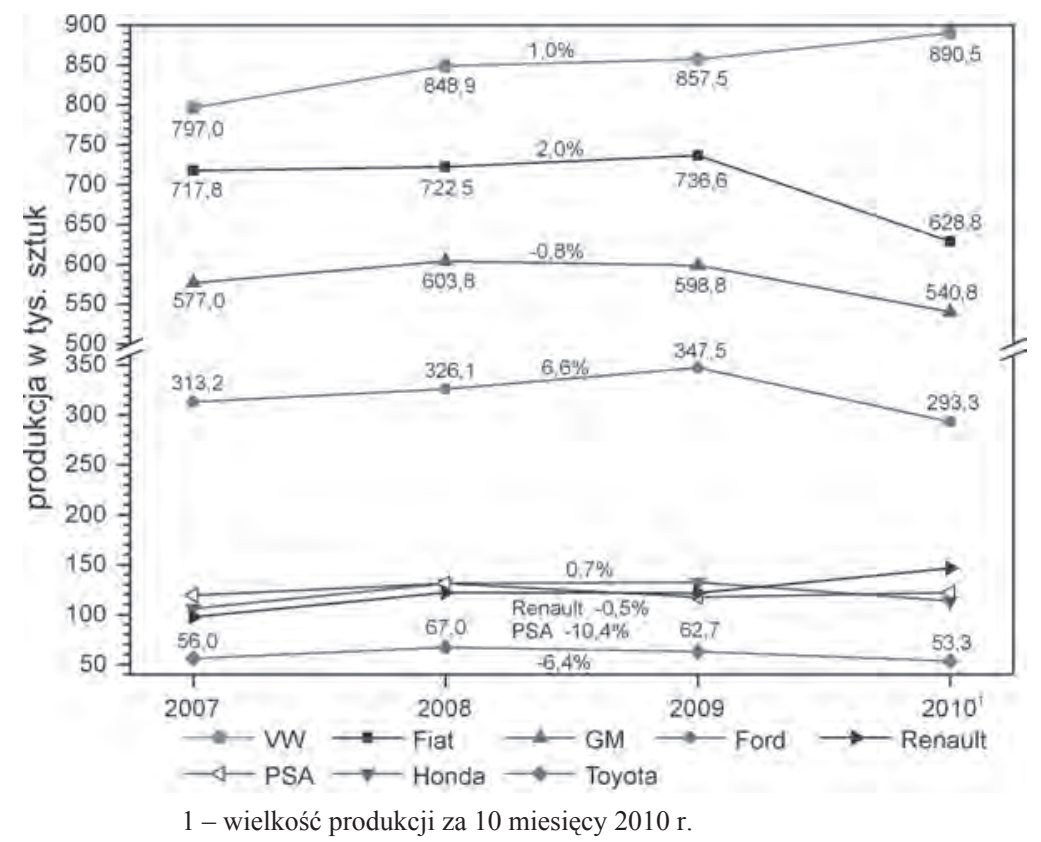

Ryc. 6. Zmiany wielkości produkcji głównych koncernów motoryzacyjnych w Brazylii w latach 2007-2010

Źródło: opracowanie na podstawie danych z ANFAVEA 2010

Stosunkowo najsilniej skutki kryzysu odczuli mniejsi producenci samochodów, którzy dodatkowo są relatywnie najkrócej obecni na brazylijskim rynku, tacy jak francuskie koncerny: PSA Peugeot Citroën i Renault. Nieznaczny spadek produkcji o 4,3 tys. sztuk, czyli o 6,4\%, odnotowała także Toyota, czego przyczyną było zakończenie w 2009 r. produkcji starszego modelu Corolla i przestawienie się wyłącznie na produkcję jego nowej wersji. W znacznie lepszej sytuacji znajdował się drugi japoński koncern samochodowy - Honda, który w latach 2008-2009 zwiększył nieznacznie produkcję o 0,7\%, do poziomu ponad 132 tys. sztuk rocznie. Firma ta była zdecydowanie bardziej zainteresowana brazylijskim 
rynkiem, produkując w swojej fabryce w Sumare (w stanie Săo Paulo) dwa modele: Civic i Fit, a od 2009 r. także City (ryc. 6).

Korzystna sytuacja gospodarcza w Brazylii, szybkie wyjście z kryzysu oraz wzrost popytu wewnętrznego na nowe pojazdy sprawiają, iż główne firmy zbliżają się do granicy zainstalowanych mocy produkcyjnych. Optymistyczne oczekiwania odnośnie dalszego rozwoju brazylijskiego rynku motoryzacyjnego - wynikające z dobrej koniunktury gospodarczej, rosnącej zamożności społeczeństwa, przy ciągle bardzo niskim wskaźniku motoryzacji - skłaniają koncerny do dalszych inwestycji w rozbudowę potencjału produkcyjnego, gdyż kraj ten staje się jednym z chłonniejszych rynków zbytu w skali światowej. Jeżeli dobra sytuacja gospodarcza w Brazylii utrzyma się, a wraz z nią tempo wzrostu gospodarczego, kraj ten będzie notował kolejną falę inwestycji w sektorze motoryzacyjnym, zwiększających i unowocześniających produkcję. Pojawiają się również nowe inwestycje greenfield, jak budowana przez Toyotę fabryka samochodów w Sorocaba, która ma rozpocząć produkcję w 2012 r., oraz rozpoczęta w grudniu 2010 r. przez Fiata budowa kompleksu przemysłowego w porcie Suape w mieście Ipojuca, leżącym ok. $40 \mathrm{~km}$ na południe od Recife w Pernambuco (tab. 2).

Tab. 2. Wielkość deklarowanych inwestycji głównych koncernów samochodowych w Brazylii w latach 2003-2009 oraz 2010-2015

\begin{tabular}{|c|c|c|c|}
\hline \multirow{2}{*}{ Koncern } & $\begin{array}{l}\text { Inwestycje } \\
\text { zapowiadane }\end{array}$ & \multicolumn{2}{|r|}{ Inwestycje deklarowane w latach 2010-2015 } \\
\hline & w mln USD & $\begin{array}{l}\text { w mln } \\
\text { USD }\end{array}$ & Główne cele \\
\hline Volkswagen & 1395 & 3600 & Modernizacja i rozbudowa fabryk, głównie w stanie Săo Paulo \\
\hline General Motors & 2348 & 2500 & $\begin{array}{l}\text { Odnowienie oferty produktowej - pełny zakres nowych } \\
\text { modeli samochodów }\end{array}$ \\
\hline Ford & 1469 & 2300 & $\begin{array}{l}\text { Rozbudowa najnowszej fabryki w Camaçari } \\
\text { w stanie Bahia }\end{array}$ \\
\hline Renault & 1020 & 580 & $\begin{array}{l}\text { Wprowadzenie do produkcji nowych modeli: Logan, Bandero } \\
\text { oraz SUV - Duster }\end{array}$ \\
\hline Fiat & 4548 & 5962 & $\begin{array}{l}\text { Nowa fabryka i kompleks przemysłowy w porcie Suape } \\
\text { w stanie Pernambuco. Rozbudowa fabryki w Betim, } \\
\text { zwiększenie o } 150 \text { tys. sztuk mocy produkcyjnych }\end{array}$ \\
\hline PSA & 296 & 700 & Rozbudowa fabryki w Porto Real \\
\hline Toyota & 1080 & 600 & $\begin{array}{l}\text { Nowa fabryka samochodów w mieście Sorocaba - } \\
\text { rozpoczęcie produkcji w } 2012 \text { r. }\end{array}$ \\
\hline Honda & 580 & - & - \\
\hline Hyundai & 717 & - & - \\
\hline Dailmer AG & 1909 & - & - \\
\hline OGÓLEM & 15360 & 16242 & \\
\hline
\end{tabular}

Źródło: opracowanie własne na podstawie: Foreign Direct Investment 2010, s. 89-92 oraz informacji ze stron internetowych koncernów z 2010 r.

Dostępne dane dotyczące deklarowanych wielkości nowych inwestycji w latach 2010 2015 wskazuja, że ich łączna wartość przekroczy 16 mld USD. Wielkość ta może jeszcze znacząco wzrosnąć, jeżeli poprawi się sytuacja finansowa tych koncernów, które ze względu 
na problemy z płynnością - obserwowane głównie w centralach - zawiesiły bądź przełożyły decyzje o inwestycjach w swoich brazylijskich oddziałach.

\section{POLITYKA ŁAGODZENIA SKUTKÓW KRYZYSU \\ W PRZEMYŚLE MOTORYZACYJNYM BRAZYLII I MEKSYKU}

Firmy motoryzacyjne działające w Meksyku zaczęły odczuwać pierwsze objawy kryzysu gospodarczego w czwartym kwartale 2008 r. W odpowiedzi na pogłębiającą się recesję wprowadzały głównie strategie redukcji kosztów stałych, polegającą na pozbywaniu się zapasów, ograniczaniu produkcji, skracaniu czasu pracy oraz zamykaniu fabryk. Starano się także ograniczać koszty zmienne poprzez redukcję zatrudnienia, szczególnie robotników niewykwalifikowanych, zmniejszenie zarobków w okresie przestojów fabryk oraz redukcję świadczeń pracowniczych (Alvarez i in. 2009; Carrillo i in. 2009; Foreign Direct Investment 2010).

W odpowiedzi na pojawiający się kryzys rząd meksykański podjął szybkie działania zmierzające do ograniczenia jego niekorzystnych skutków w tym sektorze, skupiając swoją pomoc na czterech głównych obszarach:

- programie ochrony zatrudnienia,

- liniach kredytowych i gwarancjach dla pośredników finansowych udzielających kredytów przedsiębiorstwom z tego sektora,

- programie odnowy floty pojazdów,

- różnych programach stanowych zapewniających równoległe wsparcie na poziomie lokalnym.

Program ochrony zatrudnienia został uruchomiony na początku 2009 r., z początkowym budżetem 200 mln USD, przeznaczonym dla zakładów produkujących samochody. Zakładał on pomoc firmom zmuszonym do czasowego zamykania zakładów z powodu spadku sprzedaży. Wsparcie polegało na umowie pomiędzy rządem, przedsiębiorstwem i robotnikiem, na mocy której w okresie zawieszenia zatrudnienia firma wypłacała pracownikom $2 / 3$ wcześniejszej wielkości pensji, z czego 1/3 pokrywał rząd, a pozostałą część dana firma, natomiast brakująca $1 / 3$ pensji była wkładem pracownika w walkę z kryzysem i ochronę swego miejsca pracy. Program ten był szczególnie popularny w pierwszej połowie 2009 r., gdy przestoje w fabrykach były szczególnie częste i długotrwałe. Szacuje się, iż dzięki niemu programowi udało się ocalić ok. 250 tys. miejsc pracy (Foreign Direct Investment 2010, s. 101).

Równolegle z programem ochrony miejsc pracy wprowadzono program polegający na uruchomieniu przez państwowy bank rozwojowy Nacional Financiera środków w wysokości 670 mln USD, aby zapewnić linie kredytowe i gwarancje dla banków komercyjnych i instytucji finansowych, odczuwających załamanie krajowego popytu na samochody. Program nie okazał się jednak zbyt dużym sukcesem, gdyż nie oferował bardziej elastycznych warunków ani znacząco niższych odsetek niż kredyty dostępne na rynku (Foreign Direct Investment 2010, s. 102).

Kolejnym programem pomocowym dla przemysłu motoryzacyjnego był Program Odnowy Floty Samochodowej, wzorowany na amerykańskim programie ,pieniądze za gruchoty” (Cash for Clunkers). Przeznaczono na niego ok. 36 mln USD, które przekazano producentom samochodów, w wysokości proporcjonalnej do ich udziału w meksykańskim 
rynku. Dzięki tym środkom mogli oni udzielić dopłaty w wysokości do 15 tys. pesos (1100 USD) kupującemu nowy samochód, jeśli oddał na złomowanie stary. Program okazał się jednak niezbyt atrakcyjny i skomplikowany w realizacji. Wielkość dopłaty była zbyt mało atrakcyjna w porównaniu z innymi państwami, dlatego też nie cieszył się dużym zainteresowaniem, co sprawiło, że wykorzystano jedynie połowę przeznaczonych na niego środków (Foreign Direct Investment 2010, s. 102).

Uzależnienie meksykańskiego przemysłu motoryzacyjnego od zewnętrznych rynków zbytu, szczególnie rynku USA, naraża ten sektor na silne wahania popytu niezależne od sytuacji krajowej i utrudnia pomoc dla tego sektora, gdyż przyczyny kryzysu mają zewnętrzne pochodzenie i polityka władz krajowych ma na nie niewielki wpływ. W celu umocnienia pozycji meksykańskiego przemysłu motoryzacyjnego należy więc starać się stopniowo zwiększać popyt krajowy, który uodparniałby ten sektor na zewnętrzne wahania koniunktury i wzmacniał podstawy jego dalszego rozwoju. Meksykańscy badacze oraz organizacje zrzeszające producentów samochodów sugerują, aby podjąć następujące działania zwiększające chłonność krajowego rynku:

- promowanie odnawiania floty pojazdów przez czasową eliminację podatku (ISAN) płaconego przy zakupie nowego samochodu oraz zwiększenie odliczeń podatkowych przy zakupie nowych pojazdów,

- skorygowanie standardów bezpieczeństwa oraz emisji zanieczyszczeń,

- skorygowanie struktury podatków na zakup nowych pojazdów oraz likwidację płaconego corocznie podatku od posiadania samochodu,

- zachęcanie do wprowadzania innowacji technologicznych do nowych pojazdów,

- zwiększenie dostępu do kredytów na zakup nowych pojazdów,

- usprawnienie systemu rejestracji pojazdów i dopuszczania do ruchu,

- zablokowanie bądź ograniczenie importu używanych samochodów z USA i Kanady (Carrillo i in. 2009; Foreign Direct Investment 2010, s. 102).

Brak długoterminowej polityki przemysłowej dla tego sektora utrudnia czy wręcz hamuje jego długofalowy wzrost. Biorąc pod uwagę znaczenie przemysłu motoryzacyjnego w Meksyku, zarówno pod względem wielkości zatrudnienia i udziału w tworzeniu PKB, jak również w podnoszeniu poziomu rozwoju technicznego i technologicznego, kraj ten powinien położyć większy nacisk na opracowanie długookresowej strategii rozwoju tego sektora oraz jego znaczenia w gospodarce.

W przeciwieństwie do Meksyku, brazylijski przemysł samochodowy nastawiony był głównie na zaopatrzenie rynku wewnętrznego oraz sąsiednich krajów, integrujących się w ramach MERCOSUR. Struktura produkcji brazylijskiego przemysłu motoryzacyjnego na rynek wewnętrzny i eksport była odwrotna niż w Meksyku. W Brazylii w ostatnich latach eksport pochłaniał od ok. 20 do 35\% produkcji, podczas gdy w Meksyku produkcja na rynek wewnętrzny wahała się od 17 do $31 \%$. W strukturze produktowej brazylijskiego przemysłu samochodowego dominowały małe, kompaktowe samochody osobowe, o mniejszej pojemności silnika lub napędzane silnikami flex-fuel, obniżającymi koszty eksploatacji oraz wielkość emisji szkodliwych substancji. Pojazdy te cieszyły się większą popularnością w okresie kryzysu, gdyż były zarówno tańsze przy zakupie, jak i w późniejszej eksploatacji. Natomiast w Meksyku produkowano przede wszystkim duże samochody osobowe i półciężarówki przeznaczone na rynek w USA, z silnikami o dużej pojemności, znacznie droższe i mniej ekonomiczne (Salerno Arbix 2010). 
Specyfika brazylijskiego przemysłu samochodowego zadecydowała o przyjęciu przez rząd polityki, która polegała głównie na zwiększeniu płynności finansowej w sektorze bankowym, udzielającym kredytów na zakup samochodów oraz zapewniającym płynność finansową producentom samochodów oraz ich kooperantom. Drugim działaniem podjętym przez władze była redukcja obciążeń podatkowych, związanych z uzyskaniem kredytu bądź zakupem nowych pojazdów. Szczególnie dobre rezultaty w ożywieniu popytu przyniosło wspomniane powyżej obniżenie podatku od wyrobów przemysłowych (Imposto sobre Produtos Industrializados - IPI), co doprowadziło do sytuacji, w której sprzedaż krajowa w 2009 r. przekroczyła wielkość produkcji (Salerno, Arbix 2010).

Problemem brazylijskiego przemysłu samochodowego jest utrzymanie atrakcyjności swojego rynku dla nowych inwestycji, gdyż zarówno w Meksyku, jak i Brazylii wielkość produkcji zbliżyła się do granic zainstalowanych mocy produkcyjnych. W takiej sytuacji otwiera się możliwość nowych inwestycji w tym sektorze, jednakże gwałtownie rośnie konkurencja innych państw, takich jak Chiny, Indie, Rosja czy państwa Europy ŚrodkowoWschodniej. Jakkolwiek w przypadku Brazylii deklaracje dotyczące wielkości nowych inwestycji w najbliższych latach napawają optymizmem, niemniej jednak postępująca aprecjacja brazylijskiej waluty sprawia, iż kraj ten staje się stopniowo coraz mniej atrakcyjny dla nowych inwestycji, szczególnie dla producentów części samochodowych (Foreign Direct Investment 2010, s. 104).

\section{Podsumowanie}

Przeprowadzone badania pozwalają stwierdzić, iż światowy kryzys gospodarczy, który dotknął bardzo silnie przemysł samochodowy, zwłaszcza w ostatnim kwartale 2008 r. i pierwszym półroczu 2009 r., okazał się szczególnie dotkliwy dla meksykańskiego sektora motoryzacyjnego, silnie uzależnionego od rynku zbytu w USA. Spadek produkcji w Meksyku w 2009 r. wyniósł 28,1\% i był wynikiem załamania popytu w USA oraz problemami, jakie dotknęły trzy największe koncerny tego kraju, będące zarazem głównymi inwestorami i producentami samochodów w Meksyku. Umiarkowanym sukcesem zakończyła się także polityka rządu w zakresie łagodzenia skutków kryzysu. O ile działania podjęte dla ochrony miejsc pracy w zakładach produkujących samochody zapobiegły masowym zwolnieniom i pozwoliły firmom i pracownikom przetrwać najtrudniejszą pierwszą połowę 2009 r., o tyle działania mające na celu zwiększenie popytu na rynku krajowym okazały się mało skuteczne i nie przyczyniły się do znaczącego zwiększenia sprzedaży krajowych aut. Należy podkreślić, że w dużym stopniu jest to wynikiem niedostosowania meksykańskiego przemysłu samochodowego w stosunku do możliwości i oczekiwań miejscowych klientów, nastawionych na zakup mniejszych i tańszych aut kompaktowych, często sprowadzanych przez działające w Meksyku koncerny z Brazylii, podczas gdy miejscowa produkcja, skierowana przede wszystkim na rynek USA, cechowała się dominacją głównie dużych aut, samochodów sportowo-użytkowych (SUV), półciężarówek, pickupów oraz minivanów.

Brazylijski przemysł samochodowy praktycznie nie został dotknięty długotrwałym załamaniem produkcji i po spadku w pierwszym kwartale 2009 r. udało się powrócić do wielkości produkcji sprzed kryzysu, co sprawiło, iż w skali całego 2009 r. była ona zaledwie o $1 \%$ niższa od notowanej rok wcześniej. Brazylijski przemysł samochodowy uchroniła przed 
kryzysem z jednej strony polityka wspierania popytu krajowego poprzez obniżki podatków i ułatwienia w uzyskaniu kredytu, a z drugiej odpowiednia oferta produktowa, dostosowana do możliwości finansowych konsumentów.

Podsumowując, należy stwierdzić, iż w 2010 r. przemysł samochodowy w obu krajach notuje dynamiczny wzrost produkcji, która w świetle niepełnych danych za ten rok jest już wyższa niż notowana przed kryzysem w rekordowym - jak do tej pory - 2008 roku.

\section{Literatura}

Alvarez L., Rueda I., Simon N., Castellanos J., 2009, Effects of the world economic crisis on the automobile industry based in Mexico, Paper presented at 17 Colloquium International GERPISA, June 17-19, Paris, ss. 19, http://www.gerpisa.univevry.fr/rencontre/17.rencontre/GERPISAJune2009/ Colloquium/contributions.html

AMIA 2009, 2010, AMIA-Boletin de Prensa, Asociacion Mexicana de la Industria Automotriz - AMIA, Mexico. http://www.amia.com.mx/prensa/

ANFAVEA 2009, 2010, ANFAVEA - Tabelas Estatisticas, Associaçăo Nacional dos Fabricantes de Veículos Automotores - ANFAVEA, Săo Paulo. http://www.anfavea.com.br/tabelas.html

Berry S., Grilli V., Lopez de Silanes F., 1992, The automobile industry and the Mexico - US free trade agreement, National Bureau of Economic Research Working Papers Series, no 4152, Cambridge, s. 75 .

Carrillo J., 2000, The integration of the Mexican Automobile Industry to the USA: between polices and corporate strategies, Actes du GERPISA, no. 28, s. 55-77.

Carrillo J., Contreras O., Garcia H., 2009, The automobile industry in Mexico: Confronting the current crisis, Paper presented at 17 Colloquium International GERPISA, June 17-19, Paris, s. 22. http:// www.gerpisa.univevry.fr/rencontre/17.rencontre/GERPISAJune2009/Colloquium/contributions. html

Foreign Direct Investment, 2010, Foreign Direct Investment in Latin America and the Caribbean 2009, United Nations Economic Commission for Latin America and the Caribbean - ECLAC, Santiago de Chile, s. 156.

Salerno S.M., Arbix G., 2010, Economic growth, social development and crisis management: recent evolution of the auto industry in Brazil, Paper presented at 18 Colloquium International GERPISA, June 9-11, Berlin, s. 28. http://gerpisa.org/en/node/963.

Wójtowicz M., 2008, Rozwój przemystu samochodowego w Brazylii w latach 1957-2005, [w:] Procesy transformacji układów przestrzennych przemystu na tle zmieniajacego się otoczenia, red. Z. Zioło, T. Rachwał, Prace Komisji Geografii Przemysłu PTG, nr 10, Warszawa-Kraków, s. 140-153.

Wójtowicz M., 2009, Wpływ globalizacji i integracji w ramach MERCOSUR na wymiane handlowa produktów przemystu samochodowego Brazylii w latach 1990-2006, [w:] Wpływ procesów globalizacji i integracji europejskiej na transformacje struktur przemysłowych, red. Z. Zioło, T. Rachwał, Prace Komisji Geografii Przemysłu PTG, nr 12, Warszawa-Kraków, s. 63-77.

\section{The impact of the world economic crisis on Brazilian and Mexican automobile industry}

The aim of the study is to analyze the process of economic growth and changes of Brazilian and Mexican automobile industry in years 2000-2010. Special attention was paid to the situation of those industries in the years of global economic crisis and to strategies of dealing with the production and sales slump at the turn of years 2008-2009. 
The analysis confirmed disparities between Brazilian and Mexican automobile industries' response to global economic crisis. The Mexican automobile sector was strongly affected by the slump in demand for new cars on the USA market whereas the Brazilian automobile sector experienced only a small production slowdown as the national demand for new cars soared.

Dr Mirosław Wójtowicz

Uniwersytet Pedagogiczny, Kraków

Instytut Geografii

Zakład Geografii Społeczno-Ekonomicznej

e-mail: mwojt@up.krakow.pl 